American Journal of Applied Sciences 6 (6): 1270-1276, 2009

ISSN 1546-9239

(C) 2009 Science Publications

\title{
Comparative Study of Changing Drainage Basin System with Tectonic Forms, Case Study: Lut Block, Iran
}

\author{
Ebrahim Moghimi \\ Department of Physical Geography, Geography College, University of Tehran, Iran
}

\begin{abstract}
The study area locates in the east of Iran and it is morphologic block (unit). Problem statement: Sharp contrasts in the appearances of landscapes such as drainage basins with litology (kind of rock), tectonic regime, folding and climatic effect had been inspired geomorphologies in the past and now to devise schemes to explain those contrasts. These contrasts also remained and needed to research on it locally. This problem had been explained about landscape of Lut drainage basins. So, the main problem (question) is that what entity does (nature) Lut drainage basins had in comparison with tectonic lines. The Lut geomorphologic landscape is a remarkable laboratory for the examination of early and secondly geomorphic landscape, especially drainage pattern and morpho-tectonic. Approach: Due to being the arid climatic conditions of this region now, drainage development was very little. So, there was not much information about changing drainage basin in comparison with tectonic lines. Achieving to this porous in addition to some local evidence, was using 1956 aerial photograph and TM 1998 and 2002 satellite images as well as photography and geology maps, as well as indexes of drainage density, basin area, stream length, regulation circle and river gradient, were using for drainage basins and for tectonic forms using from sinuosity index of rivers and fault and others efforts. Results: Results of this study showed that drainage basin in comparison with tectonic forms with the most frequency (inter of basins) had cut the faults and streams could cut the Lut tectonic system. Sinuosity of rivers in the Lut basins is due to morpho-tectonic effect. In the other hand territory of important Lut unit drainage basins was limited to tectonic-lines and has built the bounds of basins. So in order to, tectonic changing was new and more active than drainage network now. Conclusion: Therefore, in geomorphologic view may be refer to Lut unit as a hydro-tectonic unit.
\end{abstract}

Key words: Comparative, drainage basin, tectonic-lines, geomorphology, Lut

\section{INTRODUCTION}

Four important geomorphologic methods (attitude) to analyze the surface drainage basin which has presented up to now are:

- Method which is based on climatic factors effect and the base of this analyze are changing of climatic factors and response of surface material to climatic factors, for example Heberli and at all, for glacial $^{[12]}$, Cosandey, for hydrology ${ }^{[6]}$, Drash and Mahmodi, for river network ${ }^{[7,16]}$, Hokmy and Moatamed, for evaporates ${ }^{[14,17]}$, Moghimi, for cold and glacial climatic geomorphology ${ }^{[24]}$, for winds and changing drainage basin ${ }^{[20,21]}$

- Method which is based on analyzing of man behavior and activities in drainage basins. Increasing process of civilization and changing of drainage basins will be very improved ${ }^{[22,23,25,27]}$

- Method which is presented base on the Gilbert and Peng theory in response to Davis erosion cycle and is focused in erosion and elements denudation at time

However Gilbert in 1877, has delivered the subjects about internal correlation of basins, but hasn't said about basins bounds in one geomorphologic unit altogether $^{[5]}$. Also, Choroley ${ }^{[5]}$ has discussed about quantitative links of internal-basin. He has comforted own work base the sub-basin surveying of erosion drainage as main unit of morphology in drainage basin $^{[18,19]}$.

In his opinion the drainage basin limits to a whole specific unit with special watering. He has considered the hydrology aspect of basin has noted that drainage basin is simply zone which muster the water from surface stream and evacuate to a large stream, hollow, lake or and ocean. Such understanding from drainage basin doesn't reflect all of hydrology specifications. Other authors who discus this subject are Horton ${ }^{[13]}$, Ritter $^{[29]}$, Schumm ${ }^{[30]}$ : 
- Method which is focused on structural data. The base of study in this method is mainly stable on the structured geology attitude, such as tectonic forms, rock and folding ${ }^{[9,11]}$. Many geologist researchers refer the rock kind and sediment unit's specifications as base of the basins bound determination ${ }^{[10,17]}$. In order to, every sediment unit or rock kind can be refer as one basin ${ }^{[1,6]}$ and so that the sensitivity of sediments is different to climatic elements then may be create different drainage basins ${ }^{[13,24]}$, so may understand that every drainage basin can show one specific sediment unit and finally clarify the clear form $^{[3]}$. Duglas ${ }^{[8]}$, Bull ${ }^{[4]}$, Keller ${ }^{[15]}$, Abbasnejad ${ }^{[1]}$ and specially Oberlander ${ }^{[28]}$ have searched specially in rock and sediment unite. About tectonic effect on drainage basins has discussed rather in view of base level changing up to now ${ }^{[6]}$. Although base level changing is very important for surveying drainage basins, but doesn't show all tectonic effects on drainage basins

Whatever is more considerable for one geomorphologic observation from drainage basins as a process-response related to morpho-tectonic forms, are including:

- Geometric specification of basins and fault

- Frequency of river and faults

- Drainage explanation and changes
These parameters (in the Lut) are surveying in this article (Fig. 1). In the Lut unit may recognize four main morpho-tectonic systems that are:

- Behabad, Ravar, Zarand, Sahdad, Golbaf Bam and Mohamadabad system in the west of Lut

- Mohamad abad, Jebal barez mountain and Bazman system in the south of Lut

- Bazman, Nosratabad, Nehbandan and Birjand system in the east of Lut

- Birjand, Nayband and Behabad system in the north of Lut (Fig. 2)

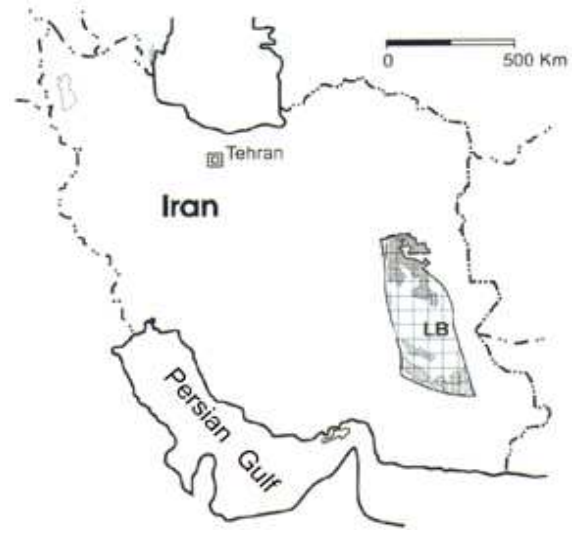

Fig. 1: Situation geomorphologic of Lut (Lut block, LB) in Iran

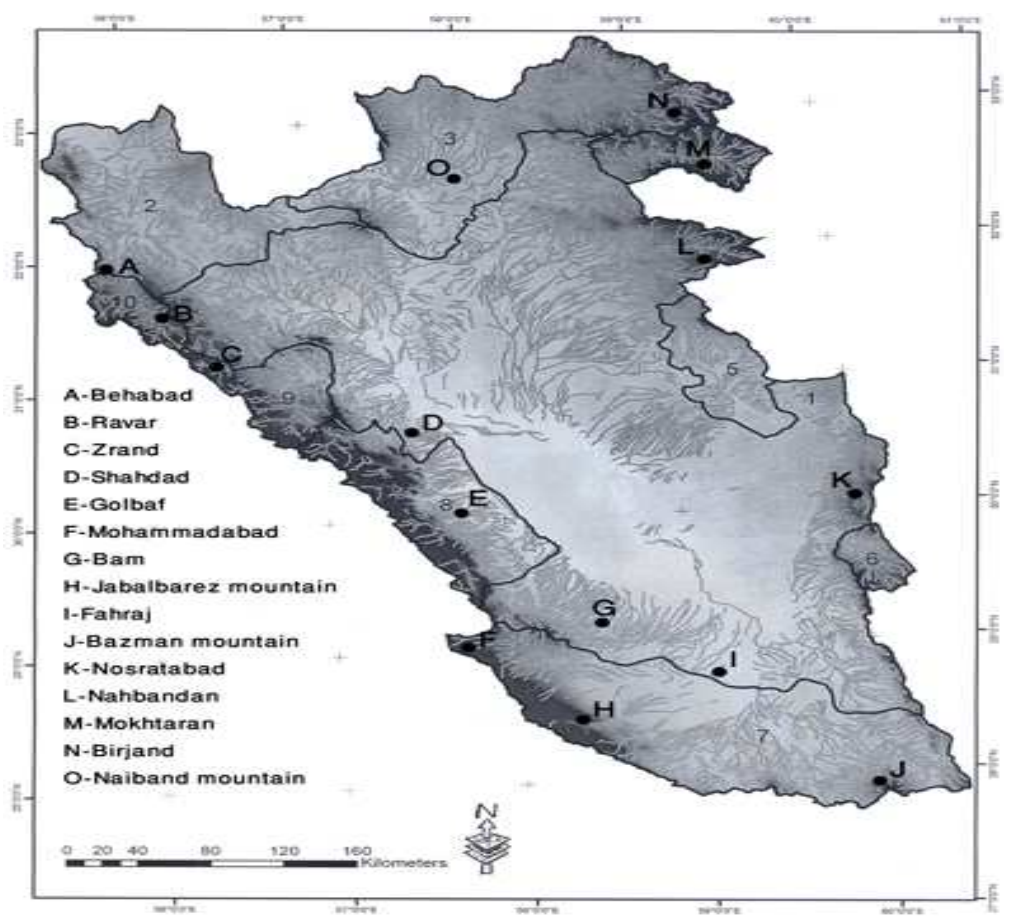

Fig. 2: Lut unit, Drainage liner forms and its main important basins (small catchments, 1-8) 


\section{MATERIALS AND METHODS}

This article using 1/40000 aerial photographs , $1 / 25000$ topography and $1 / 100000$ geology maps, as well as ETM 1998 and 2000 satellite images, ILWIS software, ARC GIS and field search. To compare the achieved data using field techniques. In order to, notice to exist data and evidence, links of variants has done by analyzing method and has compared them.

Also, using Drainage Symmetry Factor (DSF) by this equation: $D S F=100\left(\frac{A_{2}}{A_{1}}\right)$ that $A_{2}=$ minor basin area and $A_{1}=$ basin main area. In this equation, basin which its area is $50 \%$, is full context and below of it show sinuosity that can be result of tectonic activities effect in different geography directions. Furthermore, using the method of cycle ratio (RC) index, drainage density index (DDI) as well as method of River Gradient Index (RGI) which obtain by this equation: $\mathrm{RGI}=\frac{\Delta \mathrm{H}}{\Delta \mathrm{L}} \times \mathrm{L}$ that $\Delta \mathrm{H}=$ Elevation difference from two point of rivers, $\Delta \mathrm{H}=$ Horizontal distance of two sections (point) and $\mathrm{L}=$ Length of river from measure point to divide lines(head-line). Also, is used River sinuosity index which obtain by: $\mathrm{RSI}=\frac{\mathrm{C}}{\mathrm{V}}$ that $\mathrm{C}=$ Length of river and $\mathrm{V}=$ Length of valley in the straight line. Less obtained amounts in this equation are due to rather tectonic activities, as well as using Transverse Topography Isometric Factor (TTIF).

\section{RESULTS AND DISCUSSION}

The drainage basins can be result of erosion effect or initial structural data. Basins in the process of own erosion development effect on some constructional forms, such as tectonic forms, or limit on them (boundaries).

In drainage basin analyzing model of Lut block and its relationship with morpho-tectonic, at first should divide it to same small catchments (Fig. 2) and consider to following factors (Table 1):

- Lut drainage basins may be result of land erosion

- Lut drainage basins may be result of structural data

- Lut drainage basins may appear the denudation and erosion at time

- Lut drainage basins may create one sediment unit

- A Lut drainage basin prepares one system of process-response. So appear the form which show both internal system process and external system process
- Lut drainage basins are the process which today response to morpho-tectonic landforms, are surrounded (boundaries) by them and have divided drainage basins.

We should emphasize that morphology of drainage basin is complex and depends on the different climatic, hydrology, geology factors, slope and scale of form. Thus, in order to bilateral links between this factors, need to multilateral surveying. So can not discuss to surveying of Lut drainage basins with emphasize on the one index.

The reason which we emphasize it, is that one drainage basin whether is water drainage or sediment, in fact is one done system that combines with physical reflex of process-response which can be related to internal system or be affected by its adjacent systems.

Robert Horton in related to morphology of drainage basin has presented one model ${ }^{[13]}$. The model concept is including liner forms, surface forms, accumulated forms and ratio of slops altogether.

A liner form in Lut unit is dividable in two kinds. One, tectonic liner forms and other, stream liner forms (Fig. 3). Clear that tectonic liner forms are more table than stream liner forms in Lut unit, because: A) in this unit, arid climatic elements are overcome and B) tectonic liner forms are rarely active and effect of their activity are kindly observable on stream liner forms. Whatever is more observable in view of drainage basins in Lut unit are merely liner factors (tectonic-stream). Many accumulated Lut forms such as sediment alluvial cons, whether new or old, are changed by other climate elements such as erosion wind effects ${ }^{[2,23]}$. So, geometric morphology of Lut drainage basins will be a little complex.

Table 1: Drainage basin model analyzing, links of its internalsystem $^{[24]}$ and basin in Lut unit

\begin{tabular}{|c|c|c|}
\hline Drainage basin entity & Its internal-system links & Basin correlation \\
\hline \multirow[t]{2}{*}{ Is a sediment unit } & Has a same sediment & $\begin{array}{l}\text { Improve toward } \\
\text { equal }\end{array}$ \\
\hline & stability & sediment unit \\
\hline \multirow[t]{2}{*}{$\begin{array}{l}\text { Is the result of } \\
\text { structural data }\end{array}$} & $\begin{array}{l}\text { Hasn't the same } \\
\text { tectonic and }\end{array}$ & $\begin{array}{l}\text { Have delaying } \\
\text { development and is } \\
\text { different }\end{array}$ \\
\hline & lithology fusion & other adjacent basins \\
\hline $\begin{array}{l}\text { Is based on erosion } \\
\text { and denudation } \\
\text { timing }\end{array}$ & $\begin{array}{l}\text { Is affected by different } \\
\text { climatic factors }\end{array}$ & $\begin{array}{l}\text { Shows the different } \\
\text { ratio of erosion and } \\
\text { denudation }\end{array}$ \\
\hline $\begin{array}{l}\text { Is the result of Davis } \\
\text { erosion (aspect) }\end{array}$ & $\begin{array}{l}\text { Is based on the three } \\
\text { time of youth, maturity } \\
\text { and old to develop } \\
\text { drainage basin }\end{array}$ & $\begin{array}{l}\text { Shows same } \\
\text { drainage } \\
\text { accumulation }\end{array}$ \\
\hline
\end{tabular}


Am. J. Applied Sci., 6 (6): 1270-1276, 2009

Table 2: Cycle ratio, diversion from average and middle and density index of each small catchment

\begin{tabular}{llllll}
\hline $\begin{array}{l}\text { Basin } \\
\text { No. (From } \\
\text { Fig. 2) }\end{array}$ & $\begin{array}{l}\text { Drainage } \\
\text { Density } \\
\text { Index (DDI) }\end{array}$ & $\begin{array}{l}\text { Diversion } \\
\text { from } \\
\text { average }\end{array}$ & $\begin{array}{l}\text { Diversion } \\
\text { from } \\
\text { middle }\end{array}$ & $\begin{array}{l}\text { Cycle } \\
\text { ratio } \\
\text { (RC) }\end{array}$ & $\begin{array}{l}\text { Branching } \\
\text { ratio } \\
\text { (U) }\end{array}$ \\
\hline 1 & 0.23 & +0.6 & +0.5 & 0.63 & 2 \\
2 & 0.24 & +0.5 & +0.4 & 0.89 & 2 \\
3 & 0.29 & -- & -0.1 & 0.75 & 3 \\
4 & $0.0 / 31$ & -0.2 & -0.3 & 0.13 & 2 \\
5 & 0.33 & $-0.0 / 4$ & -0.5 & 0.11 & 2 \\
6 & 0.32 & $-0.0 / 3$ & -0.4 & 0.17 & 2 \\
7 & $0 / 26$ & $+0 / 3$ & $+0 / 2$ & 0.98 & 3 \\
8 & $0 / 32$ & $-0 / 3$ & $-0 / 4$ & 0.87 & 2 \\
9 & $0 / 28$ & $+0 / 1$ & -- & 0.11 & 2 \\
10 & $0 / 33$ & $-0 / 4$ & $-0 / 5$ & 0.13 & 2 \\
Average & $0 / 29$ & -- & -- & -- & -- \\
\hline
\end{tabular}

In view of geometrical morphology and elements of river environment obtain some results. Cycle ratio $(\mathrm{RC})$ which is important factor for this reason, in basin of Lut unit is changing from 11-98\% (Table 2).

One drainage basin recognize with rows of streams which introduce by $U$. In such recognition, $(\mathrm{U}+1)$, specify the point of contact between one topbrunch with U-brunch and whatever (U) be larger, introduces the larger sediment basin and the more water evacuation. In such method entrance of net liner forms to higher rank, shows the largeness of basin. But, for small catchments, is ambiguous. This amount are changing from 2-4, (Table 2).

The rank 2 have most frequency and it means that the Lut unit except in basin one, two and seven, doesn't have the large basin with larger rank, because important structures of geology with tectonic superiority limit basin growth. Brunch ratio for the largest Lut river (Rude shur) elevate to 4, (Table 2).

Surveying the Lut drainage basins show that in this region the first branch streams are more than other ranks, they are almost shorter and occupies the smaller drainage basin ${ }^{[26]}$, while the 4-branch Rivers have very low frequency. They are almost longer and occupy larger drainage basins. In addition, show that regular rivers discharge is very little due to lack of effectual perception.

Drainage density changes from $23 \%$ min (in basin 1) to $33 \%$ max (in basin 5) with $29 \%$ average in tenfold basins and with $1 \%$ diversion from average and middle, (Table 2).

These indexes show that drainage basin in response to action of erosion forces over vulnerable elements in basin, isn't very active.

All of these reasons lead us to emphasize that Lut drainage basins act as a process-response system and consider to improvement of drainage basin erosion during different time in the past. The basin deformity is more reflection of morpho-techtonic system and erosion surface process forming on faults.
Table 3: Drainage symmetry factor, river gradient and topography index and river sinuosity in the drainage basins of Lut unit

\begin{tabular}{|c|c|c|c|c|}
\hline \multirow{4}{*}{$\begin{array}{l}\text { Basin } \\
\text { No. (From } \\
\text { Fig. 2) }\end{array}$} & \multirow{4}{*}{$\begin{array}{l}\text { Drainage } \\
\text { Symmetry } \\
\text { Factor (DSF) }\end{array}$} & \multirow{4}{*}{$\begin{array}{l}\text { River } \\
\text { Gradient } \\
\text { Index (RGI) }\end{array}$} & \multicolumn{2}{|l|}{ Transverse } \\
\hline & & & Topography & River \\
\hline & & & Isometric & Sinuosity \\
\hline & & & Factor (TTIF) & Index (RSI) \\
\hline 1 & 49.30 & 30000 & 0.20 & 1.28 \\
\hline 2 & 7.10 & 4100 & 0.45 & 1.11 \\
\hline 3 & 12.00 & 5100 & 0.35 & 1.13 \\
\hline 4 & 2.50 & 1200 & 0.47 & 1.12 \\
\hline 5 & 3.40 & 1700 & 0.28 & 1.10 \\
\hline 6 & 1.13 & 800 & 0.44 & 1.30 \\
\hline 7 & 13.20 & 5800 & 0.17 & 1.60 \\
\hline 8 & 6.86 & 3700 & 0.26 & 1.28 \\
\hline 9 & 2.70 & 1300 & 0.19 & 1.10 \\
\hline 10 & 1.50 & 1400 & 0.47 & 1.20 \\
\hline
\end{tabular}

From controllers (boundaries) of Lut drainage basin, e.g., rock material, slop and sediment coverage, tectonic lines have more affection on limitation and development of Lut drainage basin and that is can consider to Lut as a Hydro-Tectonic unit.

On the other hand if Davis has emphasized that rivers can be imposed on folding structures in regional scale at first in the one surface coverage or continuous coverage $^{[3,5]}$, note that at first with forming a sediment coverage, rivers impose on it and have latitude changing on the rock surface and up to full deleting of sediment coverage, the rivers impose under structure. We can refer both subjects as the most appropriate analyzing for acting (combat) of rivers with sediment and lithology bed, provided that, the basins haven't been active tectonically.

In the Lut unit are found parts of land which due to activity of tectonic, show own active aspect, by affected on river network erosion performance and drainage basin development (Fig. 3).

Such situation has caused to prepare the appropriate place for surveying position of rivers comparison (RSI, DSF, RGI and TTIF). Sinuosity ratio of rivers (RSI) in Lut basins change from 1.28 (in basin 1) to 1.1 (in basins 5,9) (Table 3 ) and can't note any reason except morpho-tectonic reason.

The much closed equality in river sinuosity (RSI) of main rivers, show that also are affected by active morpho-tectonic. Drainage symmetry factor (DSF) changes from $1.5 \%$ (basin 10) to $49.3 \%$ (basin 1) and show that in this unit while activity is morpho-tectonic, basins are not affected by equal tectonic forces. So drainage basins haven't equal tectonic, (Table 3 and Fig. 3).

Rivers gradient index (RGI) in basins changes from 30000 (basin1) to 800 (basin 6), (Table 3). As consider the changes of RGI is very much. These changing are due to two positions: Largeness of drainage basin makes river largeness and, vertical faults 

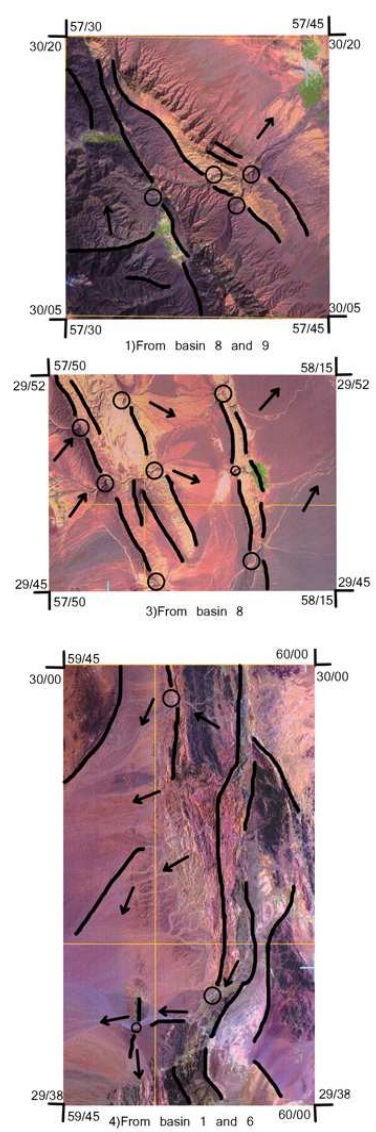
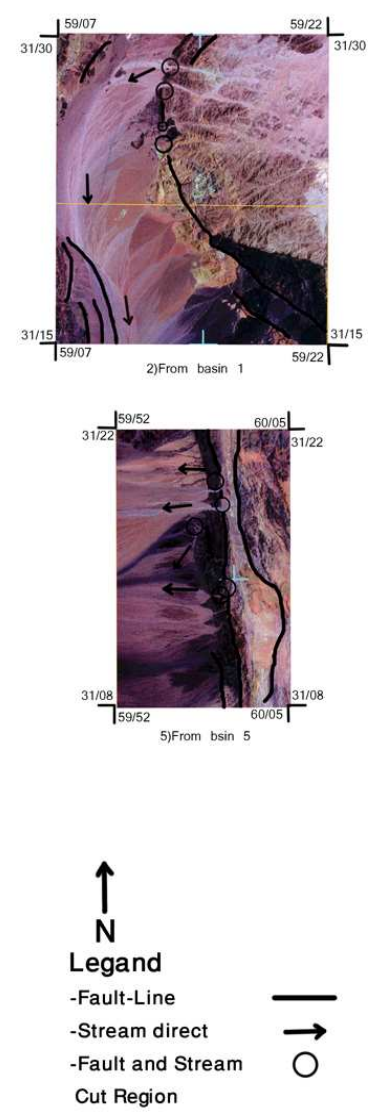

Fig. 3: Showing river network and fault lines as comparative, from number 1-5 (number I and 3 are in west of Lut unit, nomber2 in north of Lut unit and number 4 and 5 in east of Lut unit) images scale 1/100000 Land set 2002 TM

changes that can be result of changes in fault lines and faults frequency terraces landscape with increasing height. For example, basin 1 with gradient 30000 which is due to largeness of basin and basin 8 with gradient 3700 which is due to frequency of faults, are terraces landscape.

Also Topographic Transverse Isometric Factor (TTIF) show that basins haven't equal context and change from $17 \%$ minimum (basin 7) to $47 \%$ maximum (basin 4, 10), (Table 3).

Although, unequal (TTIF) of basins can be due to effect of combining the structure, lithology and tectonic. Its tectonic effect be superior on the other useful data at this factor in the Lut unit. So, drainage basin changing in Lut unit can be affected by morphotectonic landforms (Fig. 4).

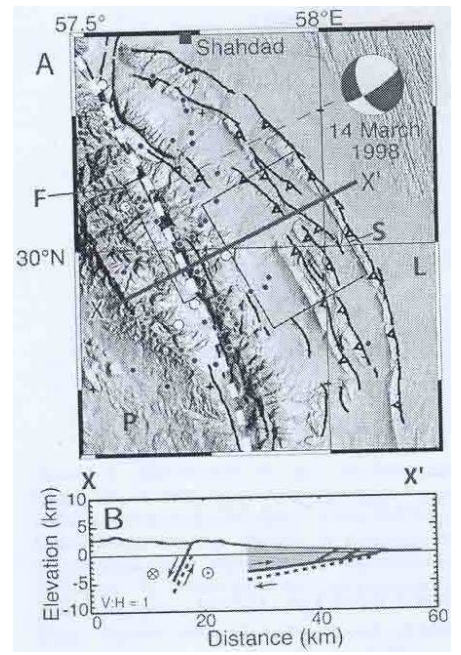

Fig. 4: Shahdad relief topographic map with active faults (A) (medium black lines), profile location (B) (thick black line), modern earthquakes (black filled circles) ${ }^{[9]}$ with stream lines

\section{CONCLUSION}

Lut unit surface is cut by number of nearly convergent water-network (streams) with unequal distances and almost flow toward central plain. Most divided line water-networks are conformed with fault lines. Tenfold main drainage basins of Lut unit have cut tectonic lines inter the basin, without consideration to lithologic barriers. In every drainage basins observe number of short rivers which they also are vertical on tectonic structures. Recognizing key for drainage basin and small catchments changes in geomorphologic Lut unit can be found in types of structural phenomena, with tectonic superiority in comparison with drainage basin, that because of being active and young, early conditions which resulted of deformity remain on it. In this unit without consider to age and other structural elements and with consider to surface geomorphologic structure, there is such understanding that in comparison with other structural forms, tectonic forms are varied and numbered the drainage basin in Lut unit are limited on them. At this time, precipitation in Lut is very little and in respect of paleogeomorphology, there are large morpho-tectonic systems in unit scale and in local scale (smaller). Maybe suppose that due to less and lack of precipitation in these basins, waterflew hadn't had enough force to cut the tectonic barriers in own path, but must notice that in this unit, rivers have cut faults in form of surprising valleys, so that river have cut fault surface in form of consequent. On the other hand formation (regulation) of Lut drainage 
basins is controlled by most of morpho-tectonic forms, both basins divided in line viewpoint and lateral development viewpoint. Erosion cycles, structures and tectonic activity have varied formation on drainage basin. The most formation are organizing with tectonic landforms. Evaluation general justification of tectonic formation may be known (note) in three position:

- Tectonic performance as compared with drainage basin structure

- Rivers performance in development toward headland on folding and unstable rocks

- Combining performance and development toward headland

Considering to surveying hydrologic indexes in this unit (e.g., DDI, RC, U, RSI, DSF, RGI and TTIF) seem that drainage basins of Lut unit are affected by tectonic performance which has occurred in past and has limited drainage basins. At this time effect of their activity are also observed on streams morphology. So, in geomorphologic view may be refer to Lut unit as a hydro-tectonic unit.

\section{ACKNOWLEDGMENT}

This article is provided the survey proposal of 4107022/01/02 number grant in title changeable drainage system surface in the Lut basin and number grant 4107022/01/04 by protection of respectable search assistant of university of Tehran, Iran.

\section{REFERENCES}

1. Abbasnejad, A., 1981. Study new tectonic from Kerman alluvial fans. Sci. Q. J. Geosci., 26: 52-59.

2. Alavipanah, S.K., H. Ahmadi and B. Komaki, 2004. A study of the geomorphological faces of yardang area of Lut desert, based upon photo orphic unit Analysis of satellite images. Iran. J. Natur. $\quad$ Res., $\quad$ 57: 21-32. http://www.cababstractsplus.org/abstracts/Abstract. aspx?AcNo=20043156946

3. Alavipanah, S.K., M. Sarajian, GH.R. Savaghebi, CH.B. Komaki, E. Moghimi and M.K. Reyhan, 2007. Land surface temperature in the Yrdang region of Lut desert based on field measurement and landsat thermal data. J. Agric. Sci. Technol., 9:

287-305.

http://www.sid.ir/En/VEWSSID/J_pdf/84820070404.pdf

4. Bull, W.B., 1984. Tectonic geomorphology. J. Educ. Geol., 32: 250-274.
5. Choroley, R., A. Stanley and S. David, 1984. Geomorphology. 1st Edn., Mehuen and Co, London, ISBN: 0-416-32590-4, pp: 316-341.

6. Cosandey, C. and N. Robinson, 2000. Hydrology Continental. 1st Edn., Armand Colin, Paris, pp: 77-121.

7. Drash, J., 1986. Comparative of jazmorian and Lut basin, translate shemirani. A, geography congers. University of MashHad Ferdosy, Iran, pp: 27.

8. Duglas, W.B. and S.A. Robert, 2001. Tectonic Geomorphology. 1st Edn., Blackwell, USA., ISBN: 0-632-04386-5, pp: 274.

9. Fielding, J.E., J.T. Wright, J. Muller, E.B. Parsons and R. Walker, 2004. Aseismic deformation of a fold-and-thrust belt imaged by synthetic aperture radar interferometry near shahdad, southeast Iran. Geol. Soc. Am. Geol. J., 32: 577-580. DOI: 10.1130/G20452.1

10. Ghazban, F., 2007. Petroleum Geology of the Persian Gulf. 1st Edn., University of Tehran, Iran, pp: 490-510.

11. Gregory, K.J. and D.E. Walling, 1973. Drainage Basin form and Process. 1st Edn., Arnold, London, pp: 22-57.

12. Heberli, W., R. Frauenfelder, M. Hoelzle and M. Maisch, 1999. Rates and acceleration trends of global glacier mass changes. Geograph. Ann., 81: 585-591. http://cat.inist.fr/?aModele=afficheN\&cpsidt=1340950

13. Horton, R.E., 1945. Erosion development of stream and their drainage basins, hydro physical approach to quantities morphology. Geol. Soc. Am., 56: 275-370. DOI: $10.1130 / 0016-$ 7606(1945)56[275:EDOSAT]2.0.CO;2

14. Hokmy, P. and J. Rashtchy, 1990. Relationship with Bain Evaporate Hedge in the Kerman Regional, (article collection), redact evaporation. University of Kerman, Iran, pp: 159-174.

15. Keller, A. and N. Pinter, 1996. Active Tectonic. 1st Edn., Prentice Hall, USA., pp: 77-95.

16. Mahmodi, F., 1978. Flow Net Work of Lut, Geography Paper, Institute of geography, No 3. Universiy of Tehran, Iran, pp: 12-21.

17. Moatamed, A. and E. Moghimi, 2009. Evaporation Geomorphology and Chemically. 1st Edn., Handbook, University of Tehran, Iran, pp: 250.

18. Motamed, A. and E. Moghimi, 2000, Geomorphology-Geology of Lut basin. National seminar on recognition of Loot (Lut) desert, (1113jan 2000). Kerman provinces Governor generals office and University of Kerman, Iran, pp: 273-278.

19. Moghimi, E. and F. Mahmudy, 2004. Research Method in Natural Geography (Geomorphology). 1st Edn., Ghoomes Publishing Company, Iran, ISBN: 964-5516-83-8, pp: 284. 
20. Moghimi, E., 2005. Fluvial Processes, Wind and Fans Changing in the Lut Plain (Daste-Lout), Researches in Geography. No. 52. Iran, pp: 139-140.

21. Moghimi, E., 2005. Winds system and Dynamic based erosion and deposition forms in Lout (Lut) plain, (Dashte-Lut). Biaban J., 11: 177-186.

22. Moghimi, E., 2005. Urban Geomorphology. Hand Book. 2nd Edn., University of Tehran, Iran, ISBN: 978-964-03-5311-10, pp: 177-187.

23. Moghimi, E., 2008. Instability of wind accumulate forms, case study: Lut plain. J. Territory, 4: 1-19.

24. Moghimi, E., 2008, Climatic Geomorphology of Cold and Glacial Territory. 1st Edn., University of Tehran, Iran, ISBN: 978-964-03-5764-4, pp: 296.

25. Moghimi, E., A. Mansourian, M. Zarei Nejad and M.S. Moghimi, 2008. Utilization of distributed architecture based on internet GIS for geomorphology data and environmental management, case study of Damavand volcano conic, Iran. Am. J. Applied Sci., 5: 1300-1307. http://www.scipub.org/fulltext/ajas/ajas51013001307.pdf
26. Moghimi, E., 2008. Small catchments, sediment yield and urban stability. Proceeding of the International Seminar on IAG (AIG), Apr. 22-23, Adam Mickiewicz University, Poland, pp: 21-22.

27. Movahed Danesh, A., 1994. Surface Water Hydrology of Iran. 1st Edn., SAMT Press, Iran, pp: 172-203.

28. Oberlander, T., 1965. Zagros streams, A New Interpretation of Transverse Drainage in an Organic Zone. Syracuse University Press, Geographical Series, No. 1, USA., pp: 103-115.

29. Ritter, D.F., R.C. KocheL, and J.R. Miller, 1995. Process Geomorphology. 4th Edn., Growhill, USA., ISBN: 0-697-34411-8, pp: 24-45.

30. Schumm, S.A., 1977. Hydrology and Fluvial Geomorphology. John Wiley and Sons, New York, pp: $42-57$. 